\title{
DAMPAK TEKNOLOGI PENDIDIKAN TERHADAP PERANAN GURU DI MASA DEPAN
}

\author{
Gusmaneli \\ Dosen Fakultas Tarbiyah IAIN Imam Bonjol Padang \\ e-mail: gusmaneli@yahoo.co.id
}

\begin{abstract}
The aim of this paper is to describe the application of technology on education and its impact on the learning process and teachers' role in the future. This is library research, where the result of analysis showed that the future education is oriented on the students' involvement on each learning activities. The students are hoped to be active and autonomous ones in using learning facilities and sources in line with the development of technology. The application of technology brings positive effect on the role of teachers in the future, which is signed by the changes of teachers' role in the teaching and learning process.
\end{abstract}

\begin{abstract}
Abstrak: Tujuan pembahasan adalah untuk menggambarkan penerapan teknologi pendidikan, dampak teknologi pendidikan terhadap proses pembelajaran, dan peranan guru di masa depan. Metode yang digunakan studi kepustakaan (library research). Hasil dari studi pustaka ini menunjukkan bahwa pendidikan dimasa depan berorientasi kepada keterlibatan dan partisipasi aktif siswa dalam setiap kegiatan belajar. Siswa diharapkan mampu mandiri dengan menggunakan berbagai macam fasilitas dan sumber belajar yang tersedia seiring dengan kemajuan ilmu pengetahuan dan teknologi pendidikan. Penerapan teknologi pendidikan membawa dampak positif terhadap peranan guru di masa depan, yang ditandai dengan berubahnya peranan guru pada masa globalisasi dari pemberi informasi yang utama dalam proses pembelajaran.
\end{abstract}

Kata Kunci: Teknologi Pendidikan, Guru, Masa Depan

\section{LATAR BELAKANG}

Perkembagan ilmu pengetahuan dewasa ini mengharuskan dunia pendidikan untuk selalu meningkatkan peningkatan mutunya. Oleh karena itu upaya peningkatan mutu pendidikan sudah merupakan kesepakatan Nasional seperti yang tertuang dalam Undang-undang Sisdiknas No 20 tahun 2003 dan undang - undang Rebublik Indonesia No 14 tahun 2005 tentang guru dan dosen, bahwa pembangunan nasional dalam bidang pendidikan adalah upaya mencerdaskan kehidupan bangsa dan meningkatkan kualitas manusia indonesia yang beriman, bertagwa, dan beraklak mulia serta menguasai ilmu pengetahuan, teknologi, dan seni dalam mewujudkan masyarakat yang maju, adil, makmur, dan beradap berdasarkan pancasila dan Undang-undang Dasar tahun 1945.

Pemerataan dan peningkatan kualitas pendidikan ditujukan untuk membentuk manusia yan terdidik yang berguna dalam kehidupan masyarakat. Untuk membentuk manusia yang terdidik tersebut dilakukan berbagai cara upaya oleh berbagai pihak, baik pemerintah maupun swasta. Di antaranya melalui proses pendidikan.
Pendidikan merupakan proses yang komplet yang dipengaruhi oleh berbagai faktor dalam pencapian tujuannya. Terganggunya salah satu komponen sistem akan berpengaruh pada komponen lain, sehingga sistem tersebut tidak akan dapat mencapai tujuannya baik.

Agar proses pendidikan berjalan dengan baik, maka kita perlu mendaya gunakan berbagai disiplin ilmu pendidikan, diantaranya penerapan teknologi pendidikan dalam sistem pendidikan.

Penerapan teknologi pendidikan merupakan salah satu cara yang dapat ilakukan untuk mengatasi kelemahan pendidikan selama ini yang dilakukan secara klasikal. Adapun kelemahan pendidikan selama ini yang dikemukakan oleh Suryosubroto (1990: 123) adalah:

1. Guru lebih banyak berfungsi dan bertugas sebagai pengajar di sekolah.

2. Guru cukup mengajar dengan texbook, secara tertulis verbalistis. Dan kebanyakan menggunakan metode ceramah.

3. Tenaga yang diperlukan adalah tenaga educatif dibantu oeleh beberapa adinistrasi 
4. Secara tradisional guru ditempatkan dan dituntut sebagai orang yang harus selalu paling tua tentang mata pelajarannya dubanding dengan murid-muridnya.

Sesuai dengan kutipan di atas. Maka pada penyelengaraan sistem pendidikan selama ini mempunyai kelemahan, sehingga tujuan yang akan dicapai tidak dapat maksimal.dalam kenyataaannya penerapan teknologi pendidikan mempunyai dampak terhadap berbagai komponen pendidikan itu sendiri, antara lain siswa, tempat belajar, guru dan proses belajar mengajar. Dampak teknologi yang utama akan terjadi pada guru, yangn mana dengan penerapan teknologi pendidikan tersebut akan sangat berpengaruh terhadap guru dalam proses belajar mengajar. Hal tersebut di atas sesuai dengan pendapat Gerlach (1979: 1), bahwa dengan penerapan teknologi pendidikan akan mengurangi beban guru dalam menyajikan informasi. Sehinggga guru dapat lebih banyak membina dan mengembangkan kegairahan belajar siswa.

Dengan demikian dapat dikatakan bahwa dalam penerapan teknologi pendidikan guru tetap memegang peranan penting, bahwa peranan tersebut lebih luas dan menyeluruh. Permasalahannya sekarang adalah bagaimanakah "Dampak Teknologi Pendidikan terhadap Peranan Guru di masa Depan”.

\section{RUANG LINGKUP DAN PEMBATASAN}

Teknologi ini akan memfokuskan pembahasan pada dampak teknologi pendidik terhadap peran guru di masa depan, dengan Masalah ruang lingkup pembahasan sebagai berikut:

1. Penerapan teknologi pendidikan untuk pendidikan masa depan

2. Dampak teknologi pendidikan terhadap proses belajar mengajar

3. Peranan guru dalam masa globalisasi.

\section{TUJUAN PENULISAN}

Penulisan jurnal ini diharapkan bertujuan untuk mengambarkan :

1. Penerapan teknologi pendidikan untuk pendidikan masa depan

2. Dampak teknologi pendidikan terhadap proses belajar mengajar
3. Peranan guru dalam masa globalisasi

\section{KEGUNAAN PENULISAN}

Penulisan jurnal ini diharapkan berguna bagi:

1. Lembaga atau instansi yang berwewenang sebagai masukan mengenai teknologi pendidikan yang dapat berperan untuk mengatasi kelemahan pendidikan.

2. Pertumbuhan ilmu pengetahuan dan teknologi pendidikan khususnya.

3. Penulis sendiri dalam rangka menambah wawasan dan pengetahuan, sehigga dapat dijadikan sebagai acuan penulis ke depan.

\section{METODOLOGI PENULISAN}

Penulisan jurnal ini menggunakan metode studi kepustakaan (library research), yaitu membaca buku-buku maupun tulisantulisan yang berhubungan dengan pembahasan yang penulis bahas.

\section{LANDASAN TEORI}

\section{PENGERTIAN TEKNOLOGI PENDIDI-} KAN

Teknologi pendidikan merupakan konsep yang kompleks, ia dapat dikaji dari berbagai segi kepentingan. Fokus teknologi pendidikan adalah memecahkan masalah belajar yang bertujuan, terarah dan terkendali. Oleh karena itu istilah "teknologi pendidikan" dipersempit menjadi "teknologi pengajaran". Miarso (2005: 544) Berdasarkan perkembangan paradigma terakhir ini, maka defenisi teknologi pembelajaran adalah teori dan pratek dalam merancang, mengembangkan, memanfaatkan, mengelola, dan menilai proses dan sumber untuk belajar. Secara operasional teknologi pendidikan dapat dikatakan sebagai proses yang bersistem dalam membantu memecahkan masalah belajar pada manusia. Kegiatan yang bersistem mengandung dua arti, yaitu pertama, yang sistemik atau beraturan, dan yang kedua yang sistemik yang beracuan pada konsep sistem. Kegiatan yang beraturan adalah kegiatan untuk memenuhi kebutuhan yang dilakukan dengan mengkaji kebutuhan itu sendiri terlebih dahulu, kemudian merumuskan tujuan, mengidentifikasi kemungkinan pencapaian tujuan dengan mempertimbangkan kendala yang ada, menentukan kriteria pemilihan kemung- 
kinan, memilih kemungkinan yang terbaik, mengembangkan dan menguji cobakan kemungkinan yang dipilih, melaksanakan hasil pengembangan dan mengevaluasi keseluruhan kegiatan maupun hasilnya.

\section{TEKNOLOGI PENDIDIKAN DALAM PENDIDIKAN}

Dengan munculnya teknologi pendidikan. Khususnya teknologi komunikasi dalam proses pendidikan akan melahirkan berbagai macam kegiatan dari pendidikan. Belajar yang dilakukan pada penerapan teknologi pendidikan akan menampilkan bentuk lain dari pada belajar yang kita kenal sekarang, dimana belajar secara klasikal dan menitik beratkan kepada peranan guru sebagai penyampaian informasi yang utama. Namun dengan penerapan teknologi pendidikan akan menimbulkan kecenderungan belajar lebih banyak secara individual atau kelompok dengan mengunakan berbagai paketpaket belajar atau program-progran belajar yang telah dirancang dan dipersiapkan sebelumnya untuk dapat digunakan oleh siswa dalam belajar secara individu atau kelompok. Oleh S. Nasution (2005:100) banyak hal yang diharapkan dari teknologi pendidikan untuk membantu mengatasi berbagai masalah pendidikan, missalnya untuk mengatasi kekurangan guru guna memenuhi aspirasi belajar penduduk yang cepat pertumbuhannya atau untuk membantu pelajar menguasai pengetahuan yang sangat pesat berkembang sehingga disebut eksplosi pegetahuan untuk membantu siswa belajar secara individual dengan lebih efektif dan efisien.

Bentuk lain yang mungkin dapat dilaksanakan adalah belajar dengan komputer dan mengunakan jasa atau peralatan audio visual, yakni penggunaan televisi atau film dan peralatan lainya yang dapat menciptakan situasi belajar.

Dengan munculnya belajar yang tidak menjadikan guru sebagai penyampai informasi yang utama, maka akan membawa berbagai kemajuan bagi peserta didiknya. Beberapa kemajuan tersebut diantara lain: membawa sistem belajar mandiri, mencari dan menemukan masalah dan memecahkan masalah sendiri dengan menggunakan berbagai sumber belajar. Memberikan kesempatan kepada siswa untuk memilih kegiatan belajar sesuai dengan minatnya. Memperluas pengalaman belajar Siswa sesuai secara verbal dan non verbal serta memperluas kesempatan belajar jarak jauh bagi siswa yang telah bekerja dan ingin melanjutkan pendidikannya.

\section{MANFAAT TEKNOLOGI PENDIDIKAN DALAM PENDIDIKAN}

Adapun manfaat yang dapat di ambil dari penerapan teknologi pendidikan adalah:

1. Mengefektifkan sistem pendidikan dari yang bersifat tradisional secara kalsikal menjadi sistem individual, terbuka dan sesuai dengan minat dan kemampuan siswa.

2. Dapat dimanfaatkan secara luas oleh masyarakat. Dengan penerapan teknologi pendidikan maka siswa dapat mengikuti pendidikan tidak terbatas tempat dan waktu untuk mengikuti pendidikan.

3. Mempunyai kelayakan dalam kelompok kecil, besar atau secara individual. Dengan berperannya teknologi pendidikan maka belajar itu dapat dilaksanakan pakah secara klasikal, kelompok kecil, besar ataupun dengan individual tergantung dengan peralatan dan materi yang akan dipelajari.

4. Mempermudah dalam penyampaian informasi baik secara verbal maupun non verbal.

Dengan berperannya teknologi pendidikan dalam dunia pendidikan, maka dapat memacu semangat para ilmuan untuk menciptakan berbagai alat atau teknologi tepat guna dalam proses pendidikan.

\section{PENERAPAN TEKNOLOGI UNTUK PEN- DIDIKAN MASA DEPAN}

Penerapan teknologi pendidikan mempunyai ciri yang menonjol yaitu dengan menggunakan alat atau media. Media tidak terbatas pada yang dipersiapkan oleh guru kelas saja. Melainkan dapat disiapkan oleh tim pengembang intruksional yang terdiri dari ahliahli dalam bidang yang bersangkutan (ahli bidang studi, ahli sistem instruksional. Ahli media dan sebagainya).

Dilihat dari segi penggunaan media, maka ada tiga kecenderungan umum untuk penggunaan media, yaitu : 
1. Dipakai secara masa, yang meliputi radio pendidikan, televisi pendidikan dan sebagainya.

2. Dipakai dalam kelompok kecil maupun besar seperti proyek film, overhead, kaset vidio dan sebagainya.

3. Dipakai secara individual, seperti mesin belajar, komputer dan sebagainya.

Bila diklasifikasikan, maka media dapat digolongkan berdasarkan biayanya, menjadi dua golongan berdasarkan biayanya. Kedua klasifikasi itu adalah "big media" dan"little media". Big media yang memerlukan biaya yang besar. Kompleksitas yang tinggi dan tenaga yang terlatih. Sedangkan little media memerlukan biaya yang relatif tidak besar, tidak rumit dan tidak harus mempunyai tenaga yang terlatih.

Dalam penggunaannya tidak ada satu media yang lebih unggul dari media lain untuk semua tujuan, maka untuk menutupi kekurangan tersebut dibutuhkan berbagai media yang saling melengkapi untuk mencapai tujuan belajar.

Dengan menggunakan multi media, maka pendayagunaan teknologi pendidikan mempunyai lima kecenderungan yaitu:

1. Meningkatkan mutu pelajaran secara langsung.

2. Secara tidak langsung dapat melatih dan menatar guru.

3. Memperluas jangkauan pendidikan.

4. Melaksanakan pendidikan dasar dan memberantas buta huruf.

5. Melanjutkan pendidikan orang dewasa dan pembangunan masyarakat.

Adapun strategi penggunaan dari kelima kecenderungan di atas berdasarkan besar kecilnya kebebasan atau kontrol atas diri pelajar.

\section{DAMPAK TEKNOLOGI PENDIDIKAN TERHADAP PROSES BELAJAR MENGA- JAR}

Dengan menerapkan teknologi pendidikan secara sistematis dapat membawa dampak terhadap proses belajar mengajar. Secara umum dapat mengefektifkan sistem pendidikan secara menyeluruh. Lebih rincinya dampak yang dapat terjadi terhadap proses belajar mengajar adalah:
1. Meningkatkan produktivitas pendidikan dengan jalan:

a. mempercepat tahab belajar

b. membantu guru untuk menggunakan waktunya lebih efektif.

c. mengurangi beban guru dalam menyajikan informasi, sehingga guru lebih banyak membina dan mengembangkan kegairahan belajar siswa.

2. Memberikan kemungkinan pendidikan yangn sifatnya lebih individual, dengan jalan:

a. mengurangi kontrol guru yang kaku dan tradisional.

b. memberikan kesempatan pada siswa untuk berkembang sesuai dengan kemampuanya.

3. Memberikan dasar yang lebih ilmiah terhadap pengajaran dengan jalan:

a. merencanakan program pengajaran yang lebih sistematis.

b. mengembangkan bahan pelajaran yang dilandasi penelitian tentang perilaku.

4. Lebih memantapkan pengajaran dengan jalan:

a. meningkatkan wawasan manusia atau siswa dengan berbagai media.

b. penyajian informasi atau lebih konkrit.

5. Memungkinkan belajar dengan seketika, karena dapat :

a. mengurangi jurang pemisah antara pelajaran dan luar sekolah.

b. memberikan pengetahuan langsung.

6. Memungkinkan penyajian pendidikan lebih luas, terutama adanya media masa dengan jalan: pemanfaatan bersama, tenaga atau kejadian yang langka. Dalam buku definisi Teknologi Pendidikan (AECT: 1986, 76) dijelaskan bahwa proses belajar mengajar dapat dikelompokkan kedalam empat pola pengajaran yaitu:

a. penyampaian materi pelajaran dari guru-siswa (sebagai pola pengajaran tradi-sional). Pola ini biasanya dilakukan memalui tatapmu ka antara guru dan siswa. Guru menyampaikan materi pelajaran dan siswa dan siswa menyerap materi tersebut. Jadi guru merupakan sumber informasi satusatunya. 
b. materi pelajaran disampaikan oleh guru dengan menggunakan alat bantu. Pola pengajaran semacam ini juga dilakukan secara tatap muka antara guru dan siswa, tetapi dalam penyampaian materiguru dibantu oleh media atau alat bantu mengajar. Penggunaan media atau alat bantu mengajar bertujuan mempermudah guru dalam menjelaskan materi yang disampaikan kepada siswa.

c. guru dan siswa berbagi tanggung jawab dalam menyampaikan materi pelajaran kepada siswa.guru tidak menyampaikan semua isi materi pelajaran kepada siswa, tetapi sebagaian isi pelajaran dapat dipelajari siswa melalui media yang tersedia. Siswa dapat dapat mencapai tujuan tertentu dengan mengikuti penjelasan guru dan siswa juga dapat mencapai tujuan pelajaran yang lainnya melalui media yang disediakan guru. Pola ini dapat dilakukan disuatus ekolah yang mempunyai sumber belajar selain guru. Sehingga pertemuan tatap muka guru dan siswa cukup menjelaskan garis besar isi pelajaran.

d. siswa mempelajari materi pelajaran yang hanya dari media saja. Siswa dapat belajar melalui media guru. Pola pengajaran seperti ini banyak digunakan pada model pendidikan jarak jauh seperti universitas terbuka dan SMP terbuka. Dengan pola seperti ini siswa tidak melakukan tatap muka secara rutin dengan gurunya. Materi pelajaran umumnya disampaikan kepada siswa melalui berbagai jenis media. Sehingga menuntut siswa untuk belajar mandiri dengan menggunakan media. Oleh sebab itu media yang digunakan harus dirancang sedemikian rupa sehingga memungkinkan siswa belajar tanpa bantuan langsung dari guru.

Keempat pola pengajaran di atas dapat digambarkan dengan pola pengajaran seperti di bawah ini:

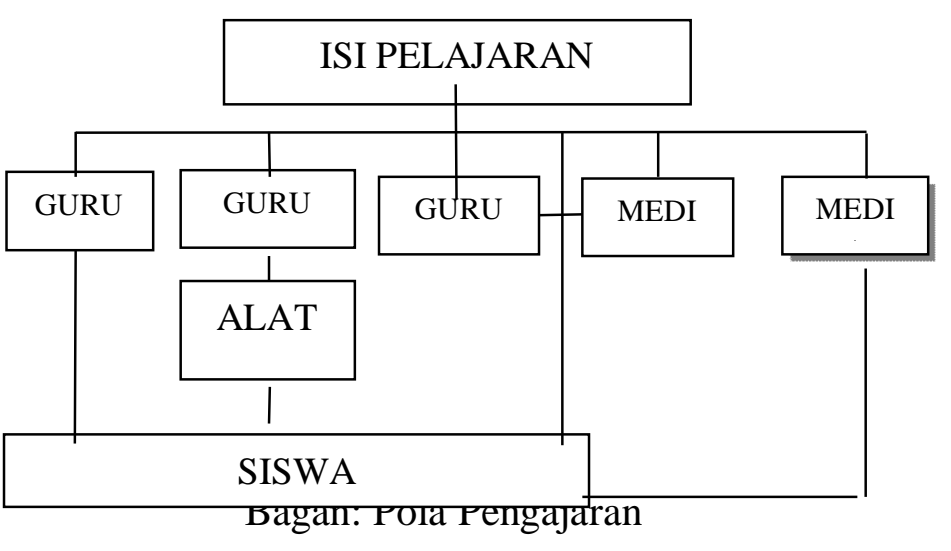

\section{PERANAN GURU DALAM MASA GLO- BALISASI}

Sebagaimana yang telah dijelaskan bahwa dalam penerapan teknologi pendidikan lebih menekankan kepada kegiatan belajar dan bukan mengajar seperti proses belajar mengajar tradisional.

Walaupun siswa diberi kebebasan dalam memilih sasaran. Tujuan serta tempat belajar dan sebagainya.tetapi dari segi pengelolaan dan kewenangan serta pengendalian masih ada pada tangan guru selaku pendidik. Dengan demikian penerapan teknologi pendidikan pada masa globalisasi ini peranan guru dalam proses belajar mengajar tetap sangat dibutuhkan.

Namun dengan penerapan teknologi pendidikan pada masa globalisasi ini akan membawa dampak terhadap peranan guru dimasa depan. Secara umum dapat kita lihat kalau ada sistem pendidikan tradisional klasikal guru adalah sebagai pemberi informasi yang utama dengan bantuan buku teks, maka pada globalisasi ini, guru bukanlah pemberi informasi yang utama (satu-satunya), melainkan peranan guru disini lebih luas dan menyeluruh.

Menurut Mulyasa (2009: 35-64) secara rinci peranan guru pada masa globalisasi ini adalah:

1. Sebagai menejer belajar, artinya dapat merencanakan, mengorganisasikan, melaksanakan, dan mengontrol kegiatan siswa belajar. Merencanakan kegiatan belajar siswa terutama menentukan tujuan belajar siswa, apa yang harus dilakukan siswa, sumbersumber belajar mana yang mungkin. Mengorganisasikan kegiatan belajar artinya menentukan dan mengarahkan bagaimana 
siswa melakukan kegiatan, sehingga dapat mencapai tujuan belajar. Dalam hal ini guru juga berperan mendorong motivasi belajar siswa. Mengoptimalisasikan sumbersumber belajar dan megatur lingkungan belajar siswa.

2. Sebagai fasilitator belajar. Artinya memberikan kemudahan-kemudahan kepada siswa dalam melakukan kegiatan belajarnya. Kemudahan ttersebut dapat diupayakan dalam bentukl menyediakan sumber dan alatalat belajar, alat peraga, menyediakan waktu yang cukup pada siswa yang memerlukannya, menunjukkan jalan keluar pemecahan masalah yang dihadapi siswa.

3. Sebagai moderator, artinya sebagai pengatur arus kegiatan belajar siswa. Sebagai moderator, guru menampung persoalan yang diajukan oleh siswa dan mengembalikan lagi persoalan tersebut pada siswa lain untuk dijawab dan dipecahkan.

4. Sebagai motivator belajar, artinya sebagai pendorong agar siswa mau melakukan kegiatan pendorong agar siswa mau melakukan kegitan belajar. Sebagai motivator guru harus menciptakan kondisi kelas yang merangsang siswa melakukan kegiatan belajar, baik kegiatan individual maupun kelompok.

5. Sebagai evaluator,artinya sebagai penilai yang objektif. Sebagai evaluator guru berkewajiban mengawasi. Memantau proses belajar siswa dan hasil-hasil belajar yang dicapainya. Di samping itu guru berkewajiban melakukan upaya perbaikan proses belajar siswa. Menunjukkan kelemahan belajar siswa dan cara memperbaikinnya baik kepada siswa secara perorangan maupun secara kelompok.

6. Sebagai tutor, artinya yang sewaktu waktuwaktu dapat memberikan bantuan bagi siswa apakah memberi petunjuk atau informasi tentang pelaksanaan proses belajar. Hal ini sering berlaku pada pendidikan jarak jauh.

7. Sebagai seorang organisator, artinya kegiatan belajar yang dibantu oleh kurikulum, tim instruksional, peneliti, teknisi dan lain-lain yang tidak langsung berintegrasi dengan siswa.
8. Sebagai Pembaharu (innovator), artinya Guru menerjemahkan pengalaman yang telah lalu kedalam kehidupan yang bermakna bagi peserta didik. Prinsip modernisasi tidak hanya diwujudkan dalam bentuk buku-buku sebagai alat utama pendidikan. Tugas guru adalah menterjemahkan kebijakan dan pengalaman yang berharga ini ke dalam istilah atau bahasa modern yang akan diterima oleh peserta didik.

9. Sebagai Pembangki Pandangan, artinya dalam hal ini guru dituntut untuk memberikan dan mememelihara pandangan tentang keagungan kepada peserta didiknya. Mengemban fungsi ini guru harus terampil dalam berkomunikasi dengan peserta didik disegala umur, sehingga setiap langkah dari proses pendidikan yang dikelolanya dilaksanakan untuk menunjang fungsi ini.

10. Sebagai pekerja rutin, artinya guru bekerja dengan keterampilan, dan kebiasan tertentu, serta kegiatan rutin yang amat diperlukan dan sering kali meberatkan. Jika kegiatan tersebut tidak dikerjakan dengan baik, maka akan bisa mengurangi atau merusak keefektifan guru pada semua peranannya. Di samping itu jika kegiatan rutin tersebut tidak disukai, bisa merusak dan mengubah sikap umumnya terhadap pembejaran. Sebagai contoh, dalam setiap kegiatan pembelajaran guru harus membuat persiapan tertulis, jika guru membenci atau tidak menyenangi tugas ini maka akan merusak keefektifan pembelajaran.

Demikian beberapa peran guru dalam masa globalisasi ini yang disebabkan peranannya teknologi pendidikan dalam dunia pendidikan sangatlah banyak.

\section{SIMPULAN}

Teknologi pendidikan adalah suatu bidang yang berkepentingan dengan kegiatan belajar yang secara sistematis berupaya mendefenisikan. Mengembangkan serta menggunakan segala macam sumber belajar dalam upaya membelajarkan siswa.

Sehubungan dengan hal itu, maka caracara belajar yang kurang mendukung kepada kreatifitas siswa perlu dirobah. Pendidikan dimasa depan akan berorientasi kepada 
keterlibatan dan partisipasi aktif siswa dalam setiap kegiatan belajar. Siswa diharapkan mampu mandiri dengan menggunakan berbagai macam fasilitas dan sumber belajar yang tersedia, semakin hari semakin canggih seiring dengan kemajuan ilmu pengetahuan dan teknologi pendidikan.

Penerapan teknologi pendidikan membawa dampak terhadap peranan guru di masa depan, yang ditandai dengan berubahnya peranan guru pada masa globalisasi dari pemberi informasi yang utama menjadi berperan sebagai pemimpin belajar, fasilitator, moderator, motivator, evaluator, tutor, inovator, dan sebagainya.
Miarso. Yusuf Hadi. 2005. Menyemai Benih Teknologi Pendidikan. Kerjasama dengan Pusat Teknologi Komunikasi dan Informasi Pendidikan Pustekkom DIKNAS.

Mulyasa. 2009. Menjadi Guru Profesional Menciptakan Pembelajaran Kreatif Dan Menyenangkan. Bandung: PT Remaja Rosda Karya.

Nasution.S. 2005. Teknologi Pendidikan. Jakarta: Bumi Aksara.

Suryo Subroto. B. 1990. Beberapa Aspek Dasar-dasar Kependidikan. Jakarta: Rineka Cipta.

Teknologi Pendidikan, Terjemah Arief Sukadi Sudiman, Dkk. Jakarta: CV. Rajawali.

Undang-undang Guru dan Dosen No 14 tahun 2005. 2008. Jakarta: Sinar

Undang-Undang Sisdiknas No 20 Tahun 2003. 2008. Jakarta: Sinar Grafika.

\section{DAFTAR RUJUKAN}

GBHN. 1993. Beserta Susunan Kabinet Pembangunan VI Semarang. Jakarta: Aneka Ilmu. 